\title{
Corneal transplant failure associated with smoking
}

\author{
Frederick W. Fraunfelder*, Murugesan Raju and Austin Strohbehn \\ Department of Ophthalmology, Mason Eye Institute, University of Missouri, Columbia, Missouri, USA
}

\begin{abstract}
This retrospective study was conducted in the University of Missouri's cornea transplant service from January 1, 2010 to September 30,2015 to determine whether smoking increases the risk of corneal transplant failure. Cornea transplant patient's records were identified via the Informatics for Integrity Biology and the Bedside data query portal using the ICD-9 codes for penetrating keratoplasty (11.64), endothelial keratoplasty (11.62, 11.63 and 11.69) and 996.51 for corneal transplant failures. A total of 257 patients were identified. The study sample was $52 \%$ female and $48 \%$ male. A total of 151 patients had penetrating keratoplasty, while 106 had endothelial keratoplasty. Penetrating keratoplasty patients with a history of smoking had a significantly higher rate of transplant failure (73\%) versus those with no history of smoking (53\%). Endothelial keratoplasty patients with a smoking history had a slightly higher rate of transplant failure (33.3\%) versus those with no history of smoking (30\%). Glaucoma patients with smoking habits also had a higher transplant failure rate (70\%) compared to glaucoma patients without a smoking history (52\%). Further, the study showed that female smokers and younger smokers $(<54)$ have higher transplant failure rates. Overall the study found that patients with a history of smoking have higher rates of corneal transplant failure than non-smokers.
\end{abstract}

\section{Introduction}

The cornea is an avascular, transparent tissue which serves as a primary window for the entire visual system. The health of the cornea can become compromised and may be unable to transmit light due to corneal diseases including Fuchs' corneal dystrophy [1], bullous keratopathy [2], corneal opacity [3], viral keratitis, and scarring from traumatic corneal injury [4,5]. Corneal opacity can occur at any age and most of the age-related corneal opacities begin as early as the fifth decade of life [6,7]. Corneal opacity is the fourth leading cause of blindness, next to cataract, glaucoma and age-related macular degeneration [8]. The Eye Bank Association of America reports that 10 million persons worldwide are blind due to corneal disorders [9].

Corneal transplantation is an effective method for visual restoration when the cornea becomes cloudy and can no longer transmit light to the retina. Corneal transplantation is the most successful type of tissue transplantation with an average of 40,000 corneal transplants being performed annually in the United States. Penetrating keratoplasty (PKP) is a full-thickness transplant procedure where all 5 layers are replaced with a donor cornea. PKP is a good option for visual restoration, however postoperative recovery time is relatively slow and there is frequently refractive error due to unpredictable astigmatism. The prolonged use of steroids following PKP also has associated side effects. The average success rate of PKP is about $50 \%$ at 10 years posttransplantation. Although PKP was once the most prominent type of corneal transplant, advances in surgical procedures has led to the use of partial thickness corneal transplants such as lamellar keratoplasty (LK) and endothelial keratoplasty (EK) including deep anterior lamellar keratoplasty (DALK), Descemet's stripping endothelial keratoplasty (DSEK), and Descemet's membrane endothelial keratoplasty (DMEK). In recent years, DMEK and DSEK have become a popular procedure in this field as they frequently produce a better visual outcome.

Many studies have reported factors that can decrease the success rate of corneal transplants. These include: recurrence of dystrophy, perforation, infection, scarring, corneal vascularization, glaucoma, glaucoma medications, and immune-mediated failure. However, there is a lack of information regarding the effect of smoking on corneal transplants. Case control studies have shown mixed information on the effects of smoking in organ transplants, however epidemiological studies have shown that smoking is a serious health issue that is associated with late allograft failure [10]. Cigarette smoke has been linked to various ocular diseases including macular degeneration, cataract, and optic nerve damage [11,12]. As very little is known about the effect of smoking on corneal transplants, we undertook this study to measure the outcome of PKPs and EKs among smokers and non-smokers by analyzing electronic health records (EHR) from the University of Missouri healthcare system using the Informatics for Integrating Biology and the Bedside (i2b2) database.

\section{Materials and methods}

MU health care is one of the largest health networks in the midMissouri region and generates a large amount of digitized clinical data that can be accessed via the i2b2 data portal. The Cerner EHR system, PathNet system, and PharmNet system provide coded data that can be extracted using International Classification of Diseases (ICD) codes. We extracted data from January 1, 2010 up until September 30, 2015, at which time the hospital adopted ICD-10 codes.

Data collection, inclusion, and exclusion criteria were followed according to the method illustrated in Figure 1. Corneal transplant patient records were identified using ICD-9 codes for PKP (11.64), EK (11.62, 11.63 and 11.69), and corneal transplant failure (996.51). Smoking status and other variables were identified using respective key words. Individuals undergoing corneal transplants were characterized with respect to age, gender, race, and other variables. The de-identified

Correspondence to: Frederick W. Fraunfelder, department of Ophthalmology, Mason Eye Institute, One Hospital Drive, Columbia, Missouri 65212, USA, Tel: 573-882-1029; Fax: 573-882-8474; E-mail: fraunfelderf@health.missouri.edu.

Key words: cornea transplant, penetrating keratoplasty, smoking

Received: June 20, 2017; Accepted: July 18, 2017; Published: July 21, 2017 


\section{Study Design: Epidemiology and Risk Factors for Corneal Transplant Failure}

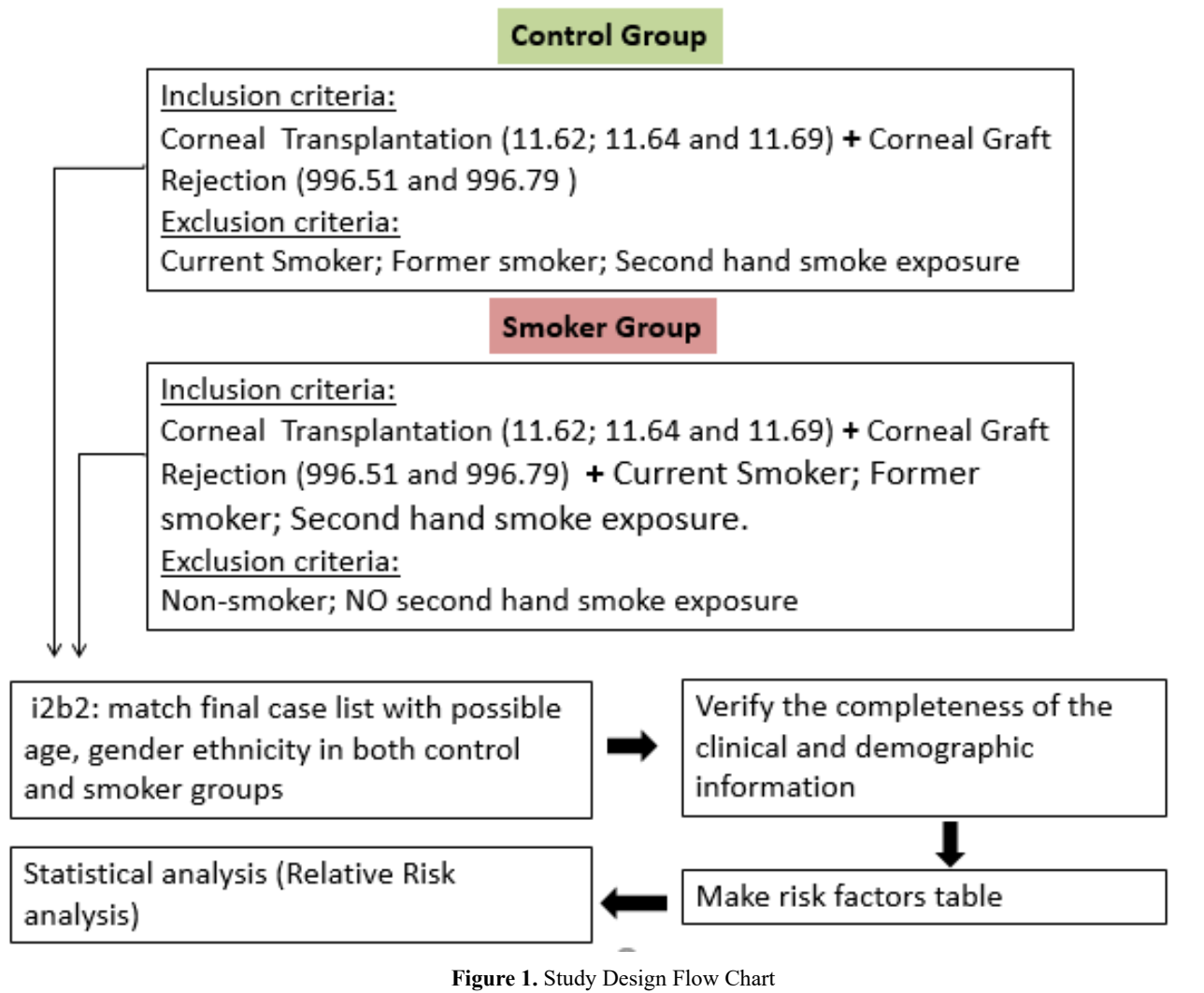

dataset, with demographic details and time stamp of clinical events, was exported to an excel work sheet. The University of Missouri Institutional Review Board approved the study protocol.

Two hundred and fifty-seven corneal transplant records were obtained, which included 151 PKPs and 106 EKs. If a patient had both PKP and EK, then they were counted independently in each group. All smoking statuses were included as it varies with time (former smoker, current smoker, heavy smoker, and light smoker). Smoking status of the corneal donors was not obtained. Other factors including glaucoma status, hypertension, and demographic information were also included for analysis.

The association between corneal transplant failure and smoking status was assessed by univariate analysis. Relative risk (RR) and $95 \%$ confidence interval (CI) were calculated according to the method described by Daly [13]. Statistical significance was chosen as $\mathrm{p}<0.05$ between smoker group vs non-smoker group. The RR was calculated between PKP and EK with and without smoking status.

\section{Results}

A total of 257 cornea transplant patients were identified. One hundred and fifty-one (58.7\%) patients had PKP and 106 (41.3\%) had EK (DMEK and DSEK). There were slightly more female (133) than male patients (124). Over $80 \%$ of the patients were 55 years or older at the time of the corneal transplant. Race was documented in approximately half of the medical records $(56.8 \%)$ and distribution of race among all cornea transplant patients was as follows: $51 \%$ Caucasian, 43\% unknown/other, 5\% African American, $>1 \%$ Asian, $>1 \%$ Hispanic. The higher proportion of Caucasian patients is reflective of the mid-Missouri population. Demographic data and clinical events of all 257 cases are reported in Table 1.
Corneal transplant failure among PKP patients with a history of smoking was $73 \%$ versus $46.3 \%$ in patients with no history of smoking $(\mathrm{p}<0.001 ; 95 \%$ CI 1.2006 to 2.0745$)$. There was no difference in the rate of corneal transplant failure between male and female non-smokers, however there was a significantly higher rate of corneal transplant failure in female smokers (92.8\%) versus male smokers $(62.9 \%)(\mathrm{p}<$ 0.001 ). There was no significant difference between the races with or without a history of smoking. The younger age groups ( $>55$ years old) with a history of smoking had a higher rate of corneal transplant failure than the older age groups ( $\mathrm{p}<0.005 ; 95 \%$ CI 1.2986 to 4.575 ). Detailed analysis of the PKP data can be found in Table 2. In PKP patients with glaucoma, smokers had a higher rate of corneal transplant failure $(70 \%)$ than non-smokers (52.3\%) (Table 3).

There was no signifcant difference in the rate of corneal transplant failure among smoking and non-smoking patients who had undergone EK (Table 4). Further analysis with a larger number of EK patients is required to validate this finding.

Overall, patients who had PKP had a higher rate of corneal transplant failure than those who had EK. Similarly, patients with a history of smoking had a higher rate of corneal transplant failure with PKP versus EK (Figure 2).

\section{Discussion}

Many risk factors have been linked with poor survival rate of corneal transplants including diabetes, glaucoma, glaucoma surgeries, and its related medication. However, no studies have addressed the effect of smoking on corneal transplantion. There is no consistent result in the literature regarding the effect of smoking on other organ transplants. The epidemiology of corneal transplant failure is complex, diverse, 
Table 1. Demographic and Clinical Data of all Cornea Transplant Patients

\begin{tabular}{|c|c|c|c|c|}
\hline & Description & Total & $\begin{array}{l}\text { Corneal Transplant } \\
\text { Complication }\end{array}$ & $\%$ \\
\hline \multirow[t]{3}{*}{ Corneal transplant } & & 257 & 113 & 43.97 \\
\hline & Penetrating keratoplasty (11.64) & 151 & 61 & 40.40 \\
\hline & Other corneal transplant $(11.63,11.69)$ & 106 & 52 & 49.06 \\
\hline \multirow[t]{2}{*}{ Glaucoma } & No & 216 & 69 & 31.94 \\
\hline & Yes & 41 & 25 & 60.98 \\
\hline \multirow[t]{2}{*}{ Glaucoma surgery } & No & 240 & 84 & 35.00 \\
\hline & Yes & 17 & 10 & 58.82 \\
\hline \multirow[t]{2}{*}{ Glaucoma medication } & No & 161 & 56 & 34.78 \\
\hline & Yes & 96 & 38 & 39.58 \\
\hline \multirow[t]{2}{*}{ Smoker } & No & 195 & 76 & 38.97 \\
\hline & Yes & 62 & 37 & 59.68 \\
\hline \multirow[t]{2}{*}{ Hypertension } & No & 135 & 46 & 34.07 \\
\hline & Yes & 122 & 48 & 39.34 \\
\hline \multirow[t]{6}{*}{ Corneal diagnostic } & Bullous keratopathy (371.23) & 44 & 20 & 45.45 \\
\hline & Corneal anesthesia and hypoesthesia (371.81) & 1 & 0 & 0.00 \\
\hline & Keratoconus (166) & 25 & 11 & 44.00 \\
\hline & Endothelial corneal dystrophy (371.57) & 83 & 35 & 42.17 \\
\hline & Corneal edema due to wearing of contact lenses (371.24) & 1 & 0 & 0.00 \\
\hline & Other posterior corneal dystrophies $(371.58)$ & 1 & 1 & 100.00 \\
\hline \multirow[t]{2}{*}{ Gender } & Male & 124 & 52 & 41.94 \\
\hline & Female & 133 & 61 & 45.86 \\
\hline \multirow[t]{4}{*}{ Age } & $0-17$ & 4 & 2 & 50.00 \\
\hline & $18-54$ & 47 & 24 & 51.06 \\
\hline & $55-74$ & 107 & 41 & 38.32 \\
\hline & $>75$ & 99 & 46 & 46.46 \\
\hline \multirow[t]{5}{*}{ Race } & African American & 13 & 9 & 69.23 \\
\hline & White & 130 & 67 & 51.54 \\
\hline & Asian & 2 & 1 & 50.00 \\
\hline & Hispanic & 1 & 1 & 100.00 \\
\hline & Others /UK & 111 & 35 & 31.53 \\
\hline
\end{tabular}

Table 2. PKP and Corneal Transplant Failure Among Smokers and Non-Smokers

\begin{tabular}{|c|c|c|c|c|c|c|c|c|c|c|c|c|c|}
\hline & & \multicolumn{9}{|c|}{ Penetrating Keratoplasty (PKP) } & \multicolumn{3}{|c|}{$\begin{array}{c}\text { Transplant Failure } \\
\text { Smoker vs Non-Smoker }\end{array}$} \\
\hline & & \multirow[t]{2}{*}{$\begin{array}{l}\text { Total No. } \\
\text { of PKPs }\end{array}$} & \multicolumn{2}{|c|}{$\begin{array}{c}\text { Total } \\
\text { Transplant } \\
\text { Failure }\end{array}$} & \multirow[t]{2}{*}{ Smokers } & \multicolumn{2}{|c|}{$\begin{array}{c}\text { Smoker + } \\
\text { Transplant } \\
\text { Failure }\end{array}$} & \multirow[t]{2}{*}{ Non-Smokers } & \multicolumn{2}{|c|}{$\begin{array}{c}\text { Non-Smokers }+ \\
\text { Transplant Failure }\end{array}$} & \multirow[t]{2}{*}{$\begin{array}{c}\text { Relative } \\
\text { Risk }\end{array}$} & \multirow[t]{2}{*}{$95 \% \mathrm{CI}$} & \multirow[t]{2}{*}{$P$ value } \\
\hline & & & $\mathbf{N}$ & $\%$ & & $\mathbf{N}$ & $\%$ & & $\mathbf{N}$ & $\%$ & & & \\
\hline & PKPs & 151 & 81 & 53.6 & 41 & 30 & 73.1 & 110 & 51 & 46.3 & 1.5782 & 1.2006 to 2.0745 & 0.0011 \\
\hline \multirow[t]{2}{*}{ Gender } & Male & 81 & 38 & 46.9 & 27 & 17 & 62.9 & 54 & 21 & 38.8 & 1.6190 & 1.0405 to 2.5193 & 0.0327 \\
\hline & Female & 70 & 43 & 61.4 & 14 & 13 & 92.8 & 56 & 30 & 53.5 & 1.7333 & 1.3050 to 2.3022 & 0.0001 \\
\hline \multirow[t]{5}{*}{ Race } & Black & 12 & 8 & 66.6 & 6 & 5 & 83.3 & 6 & 3 & 50.0 & 1.6667 & 0.6937 to 4.0043 & 0.2534 \\
\hline & White & 69 & 46 & 66.6 & 33 & 24 & 72.7 & 36 & 22 & 61.1 & 1.1901 & 0.8522 to 1.6620 & 0.3072 \\
\hline & Asian & 1 & 0 & 0 & 0 & 0 & 0 & 1 & 0 & 0 & - & - & - \\
\hline & Hispanic & 1 & 1 & 100 & 1 & 1 & 100 & 0 & 0 & 0 & - & - & - \\
\hline & Other/UK & 68 & 26 & 38.2 & NA & NA & NA & NA & NA & NA & NA & NA & NA \\
\hline \multirow[t]{4}{*}{ Age } & 0-17 & 4 & 2 & 50.0 & 0 & 0 & 0 & 2 & 2 & 100 & - & - & - \\
\hline & $18-54$ & 46 & 23 & 50.0 & 20 & 15 & 75.0 & 26 & 8 & 30.7 & 2.4375 & 1.2986 to 4.5751 & 0.0055 \\
\hline & $55-74$ & 61 & 32 & 52.4 & 13 & 9 & 69.2 & 48 & 23 & 47.9 & 1.4448 & 0.9055 to 2.3054 & 0.1227 \\
\hline & $>75$ & 40 & 24 & 60.0 & 8 & 6 & 75.0 & 32 & 18 & 56.2 & 1.3333 & 0.8059 to 2.2058 & 0.2627 \\
\hline
\end{tabular}

Table 3. Glaucoma and Cornea Transplant Failure Among Smokers and Non-Smokers

\begin{tabular}{|c|c|c|c|c|c|c|}
\hline Total PKPs & Glaucoma & Glaucoma + Smoker & \multicolumn{2}{|c|}{ Glaucoma + Smoker + Failure } & $\begin{array}{c}\text { Glaucoma + Non- } \\
\text { Smoker }\end{array}$ & \multicolumn{2}{c|}{ Glaucoma + Non-Smoker + Failure } \\
\hline N & N & N & N & $\%$ & N & N \\
\hline 151 & 41 & 20 & 14 & 70 & 21 \\
\hline
\end{tabular}


Table 4. EK and Corneal Transplant Failure Among Smokers and Non-Smokers

\begin{tabular}{|c|c|c|c|c|c|c|c|c|c|c|c|c|c|}
\hline & & \multicolumn{9}{|c|}{ Endothelial Keratoplasty (EK, DMEK and DSEK ) } & \multicolumn{3}{|c|}{ Graft Failure Smoker vs Non-Smoker } \\
\hline & & \multirow[t]{2}{*}{$\begin{array}{c}\text { Total No. } \\
\text { of EKs }\end{array}$} & \multicolumn{2}{|c|}{$\begin{array}{c}\text { Total } \\
\text { Transplant } \\
\text { Failure }\end{array}$} & \multirow[t]{2}{*}{ Smokers } & \multicolumn{2}{|c|}{$\begin{array}{c}\text { Smoker + } \\
\text { Transplant } \\
\text { Failure }\end{array}$} & \multirow[t]{2}{*}{ Non-Smokers } & \multicolumn{2}{|c|}{$\begin{array}{c}\text { Non-Smokers }+ \\
\text { Transplant Failure }\end{array}$} & \multirow[t]{2}{*}{$\begin{array}{c}\text { Relative } \\
\text { Risk }\end{array}$} & \multirow[t]{2}{*}{$95 \% \mathrm{CI}$} & \multirow[t]{2}{*}{$P$ value } \\
\hline & & & $\mathbf{N}$ & $\%$ & & $\mathbf{N}$ & $\%$ & & $\mathbf{N}$ & $\%$ & & & \\
\hline & EKs & 106 & 32 & 30.1 & 21 & 7 & 33.3 & 85 & 25 & 29.4 & 1.133 & 0.5692 to 2.2567 & 0.7217 \\
\hline \multirow[t]{2}{*}{ Gender } & Male & 43 & 14 & 32.5 & 9 & 4 & 44.4 & 34 & 10 & 29.4 & 1.511 & 0.6162 to 3.7058 & 0.3670 \\
\hline & Female & 63 & 18 & 28.5 & 12 & 3 & 25.0 & 51 & 15 & 29.4 & 0.850 & 0.2921 to 2.4738 & 0.7656 \\
\hline \multirow[t]{5}{*}{ Race } & Black & 1 & 1 & 100 & 0 & 0 & 0 & 1 & 1 & 100 & - & - & - \\
\hline & White & 61 & 21 & 34.4 & 20 & 6 & 30.0 & 41 & 15 & 36.5 & 0.820 & 0.3754 to 1.7913 & 0.6186 \\
\hline & Asian & 1 & 1 & 100 & 1 & 1 & 100 & 0 & 0 & 0 & - & - & - \\
\hline & Hispanic & 0 & 0 & 0 & 0 & 0 & 0 & 0 & 0 & 0 & - & - & - \\
\hline & Other/UK & 43 & 9 & 20.9 & NA & NA & NA & NA & NA & NA & NA & NA & NA \\
\hline \multirow[t]{4}{*}{ Age } & 0-17 & 0 & 0 & 0 & 0 & 0 & 0 & 0 & 0 & 0 & - & - & - \\
\hline & $18-54$ & 1 & 1 & 100 & 0 & 0 & 0 & 1 & 1 & 100 & - & - & - \\
\hline & $55-74$ & 46 & 9 & 19.5 & 11 & 3 & 27.2 & 35 & 6 & 17.1 & 1.590 & 0.4749 to 5.3300 & 0.4516 \\
\hline & $>75$ & 59 & 22 & 37.2 & 10 & 4 & 40.0 & 49 & 18 & 36.7 & 1.088 & 0.4685 to 2.5308 & 0.8431 \\
\hline
\end{tabular}

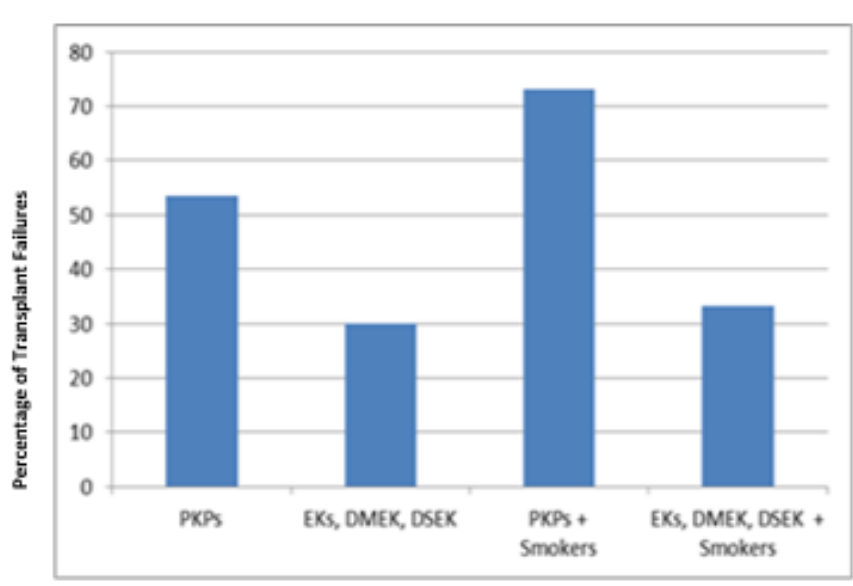

Figure 2. Comparison of Corneal Transplant Failure Among PKP and EK Patients

and varies from individual to individual. Many factors determine the survival rate of corneal transplant, including genetic variation and exposures of various endogenous and exogenous factors [1416]. Although many clinicians perform corneal transplants, few have undertaken studies to investigate their outcome. Short-term, followup studies (up to 2 years) have reported success rates of up to $90 \%$ or higher in specific regions, while a few long-term studies have reported survival rates above $50 \%$ at 10 years [17]. The Australian Corneal Graft Registry shows a 10 -year survival rate of $50 \%$ to $70 \%$ [18]. Similar observations were reported by the National Eye Institute Collaborative Corneal Transplantation Study [19], the United Kingdom and the Republic of Ireland Corneal Transplant Follow-up Study [20], and the Canadian Corneal Graft Outcome Study [21]. In 2008, the Australian Corneal Graft Registry reported a 10-year corneal transplant survival rate of $40 \%$ when the transplant was performed for pseudophakic and aphakic corneal edema, 60\% for herpetic corneal scars, 73\% for Fuchs' corneal dystrophy, and $89 \%$ for keratoconus [18]. This present study from MU healthcare data reports a $60 \%$ overall cumulative survival rate (0-6 years) with the rate of corneal transplant failures of $53 \%$ and $30 \%$ in PKPs and EKs respectively.

The burning of cigarettes releases as many 6,000 different compounds including nicotine, tobacco glycoprotein, and many toxic chemicals such as hydrocarbons, carbon monoxide, aldehydes, and heavy metals [22]. These toxic agents can cause irreversible damage to proteins and cellular systems and several studies have reported that smoking is the leading cause of ocular surface damage [23-26]. The outer layer of the cornea provides a defense mechanism and barrier to the external environment. Smoking can directly affect corneal epithelial tissue by both passive and active inhalations of smoke. The innermost endothelial layer of the cornea is a thin, monolayer of cuboidal cells covering the posterior side of Descemet's membrane which plays a key role in regulating the hydration level of the cornea through an active ATP and bicarbonate-dependent pump. Studies have reported that cigarette smoke affects endothelial cell count, guttata development, and morphological changes [27-29]. Corneal endothelial cells are sensitive to hypoxia and cigarette smoke-related hypoxia may put the endothelial cells at risk leading to corneal transplant failure.

Smoking affects both innate and adaptive immunity including inflammation and autoimmunity in many disease conditions [30]. Cigarette smoke has been shown to increase many pro-inflammatory cytokines such as IL-1, 6, 8, and TNF- $\alpha$ and decreased the antiinflammatory molecule IL-10 [30,31]. Vittecoq et al reported that patients with a history of smoking and who carry at least one copy of the HLA DRB1 are at an increased risk for inflammatory disease [32]. Further case control studies with genomic and proteomics analysis could lead to the identification of potential markers in patients with a smoking history to predict corneal transplant failure.

The i2b2 database has many advantages, however it comes with limitations including an inability to comprehensively query beyond diagnosis and procedural coding. It is also limited by the data that the hospital provides. These limitations are typical of a retrospective analysis.

Overall, this study indicates that cigarette smoke plays a role in cornea transplant failure. Future studies will examine what happens at the molecular level to corneal transplants that fail in patients who smoke.

\section{Acknowledgement}

We thank Bree Jensvold-Vetsch for her help with the preparation of the manuscript. We also thank Dr. Abu Mosa, Director, Research Informatics, Health Management \& Informatics for his help in accessing the $\mathrm{i} 2 \mathrm{~b} 2$ database. 


\section{References}

1. Lin ZN, Chen J, Cui HP1 (2016) Characteristics of corneal dystrophies: a review from clinical, histological and genetic perspectives. Int J Ophthalmol 9: 904-913. [Crossref]

2. Morrison LK, Waltman SR (1989) Management of pseudophakic bullous keratopathy. Ophthalmic Surg 20: 205-210. [Crossref]

3. Ciralsky J, Colby K (2007) Congenital corneal opacities: a review with a focus on genetics. Semin Ophthalmol 22: 241-246. [Crossref]

4. Maeno A, Naor J, Lee HM, Hunter WS, Rootman DS. (2000) Three decades of corneal transplantation: indications and patient characteristics. Cornea 19: 7-11. [Crossref]

5. Nicholls SM, Shimeld C, Easty DL, Hill TJ (1996) Recurrent herpes simplex after corneal transplantation in rats. Invest Ophthalmol Vis Sci 37: 425-435. [Crossref]

6. Farley R (1988) After the starting line: blacks and women in an uphill race. Demography 25: 477-495. [Crossref]

7. Salvi SM, Akhtar S, Currie Z (2006) Ageing changes in the eye. Postgrad Med J 82: 581-587. [Crossref]

8. WHO. Global Data on Visual Impairments 2010 (WHO/NMH/PBD/12.01) world Health Organization, Geneva. 2010.

9. Eye Bank Association of America. 2015 Eye banking Statistical report. Washington, DC. www.restoresight.org.

10. Wan F, Dai H, Zhang S, Moore Y, Wan N, et al. (2012) Cigarette smoke exposure hinders long-term allograft survival by suppressing indoleamine 2, 3-dioxygenase expression. Am J Transplant 12: 610-619. [Crossref]

11. Jetton JA, Ding K, Kim Y, Stone DU (2014) Effects of tobacco smoking on human corneal wound healing. Cornea 33: 453-456. [Crossref]

12. Solberg Y, Rosner M, Belkin M (1998) The association between cigarette smoking and ocular diseases. Surv Ophthalmol 42: 535-547. [Crossref]

13. Daly LE (1998) Confidence limits made easy: interval estimation using a substitution method. Am J Epidemiol 147: 783-790. [Crossref]

14. Whitcher JP, Srinivasan M, Upadhyay MP (2001) Corneal blindness: a global perspective. Bull World Health Organ 79: 214-221. [Crossref]

15. Dandona L, Naduvilath TJ, Janarthanan M, Ragu K, Rao GN (1997) Survival analysis and visual outcome in a large series of corneal transplants in India. Br J Ophthalmol 81: 726-731. [Crossref]

16. Yang Y, Lu C, Zhao J, Wu Y, Cao G (2000) [Optimal treatment parameters for damage of chicken comb vessels using chlorophyll derivative IV in photodynamic therapy]. Hua Xi Kou Qiang Yi Xue Za Zhi 18: 159-162. [Crossref]

17. Bourne WM (2001) Cellular changes in transplanted human corneas. Cornea 20: 560 569. [Crossref]
18. Williams KA, Lowe M, Bartlett C, Kelly TL, Coster DJ; All Contributors (2008) Risk factors for human corneal graft failure within the Australian corneal graft registry. Transplantation 86: 1720-1724. [Crossref]

19. Sugar J (1992) The Collaborative Corneal Transplantation Studies. Arch Ophthalmol 110: 1517-1518. [Crossref]

20. Vail A, Gore SM, Bradley BA, Easty DL, Rogers CA, et al. (1997) Conclusions of the corneal transplant follow up study. Collaborating Surgeons. Br J Ophthalmol 81: 631-636. [Crossref]

21. Sit M, Weisbrod DJ, Naor J, Slomovic AR (2001) Corneal graft outcome study. Cornea 20: 129-133. [Crossref]

22. Smith CJ, Hansch C (2000) The relative toxicity of compounds in mainstream cigarette smoke condensate. Food Chem Toxicol 38: 637-646. [Crossref]

23. van der Vaart H, Postma DS, Timens W, ten Hacken NH (2004) Acute effects of cigarette smoke on inflammation and oxidative stress: a review. Thorax 59: 713-721. [Crossref]

24. Matsumoto Y, Dogru M, Goto E, Sasaki Y, Inoue H, et al. (2008) Alterations of the tea film and ocular surface health in chronic smokers. Eye (Lond) 22: 961-968. [Crossref]

25. Altinors DD, Akça S, Akova YA, Bilezikçi B, Goto E, et al. (2006) Smoking associated with damage to the lipid layer of the ocular surface. Am J Ophthalmol 141: 1016-1021. [Crossref]

26. Satici A, Bitiren M, Ozardali I, Vural H, Kilic A, et al. (2003) The effects of chronic smoking on the ocular surface and tear characteristics: a clinical, histological and biochemical study. Acta Ophthalmol Scand 81: 583-587. [Crossref]

27. Ilhan N, Ilhan O, Coskun M, Daglioglu MC, Ayhan Tuzcu E, et al. (2016) Effects of Smoking on Central Corneal Thickness and the Corneal Endothelial Cell Layer in Otherwise Healthy Subjects. Eye Contact Lens 42: 303-307. [Crossref]

28. Zoega GM, Fujisawa A, Sasaki H, Kubota A, Sasaki K, et al. (2006) Prevalence and risk factors for cornea guttata in the Reykjavik Eye Study. Ophthalmology 113: 565569. [Crossref]

29. Sayin N, Kara N, Pekel G, Altinkaynak H (2014) Effects of chronic smoking on centra corneal thickness, endothelial cell, and dry eye parameters. Cutan Ocul Toxicol 33: 201-205. [Crossref]

30. Arnson Y, Shoenfeld Y, Amital H (2010) Effects of tobacco smoke on immunity, inflammation and autoimmunity. J Autoimmun 34: J258-265. [Crossref]

31. Hagiwara E, Takahashi KI, Okubo T, Ohno S, Ueda A, et al. (2001) Cigarette smoking depletes cells spontaneously secreting $\mathrm{Th}(1)$ cytokines in the human airway. Cytokine 14: 121-126. [Crossref]

32. Vittecoq O, Lequerré T, Goëb V, Le Loët X, Abdesselam TA, et al. (2008) Smoking and inflammatory diseases. Best Pract Res Clin Rheumatol 22: 923-935. [Crossref]

Copyright: (C2017 Fraunfelder FW. This is an open-access article distributed under the terms of the Creative Commons Attribution License, which permits unrestricted use, distribution, and reproduction in any medium, provided the original author and source are credited. 